\title{
Photodynamic Therapy for Recurrent Head and Neck Malignancy
}

\author{
Yong-Sik Lee, Young-Chang Lim, Yeo-Jin Lee, Mun-Su Park and Jae-Myeong Kim \\ Department of Otolaryngology-Head and Neck Surgery, Konkuk University School of Medicine, Seoul, Korea
}

재발한 두경부암에서 라다클로린을 이용한 광역동치료

이용식 · 임영창 - 이여진 · 박문수 · 김재명

건국대학교 의학전문대학원 이비인후-두경부외과학교실

Received December 15, 2010

Revised February 11, 2011

Accepted February 15, 2011

Address for correspondence

Yong-Sik Lee, MD

Department of Otolaryngology-

Head and Neck Surgery,

Konkuk University

School of Medicine,

4-12 Hwayang-dong, Gwangjin-gu,

Seoul 143-729, Korea

Tel $+82-2-2030-7669$

Fax +82-2-2030-5299

E-mail yslee@kuh.ac.kr
Background and Objectives As a preliminary study, authors tried to verify clinical and side effects of Radachlorin in a photodynamic therapy for recurrent head and neck malignancy. Radachlorin shows an absorption peak at $662 \mathrm{~nm}$, which indicates that it penetrates up to $10 \mathrm{~mm}$.

Subjects and Method We treated 12 sites for 9 treatments in 6 recurrent head and neck malignacies, 4 cases of squamous cell cancers and each of adenoid cystic cancer, and undifferentiated nasopharyngeal cancer. A dose of $1 \mathrm{mg} / \mathrm{kg}$ or $2-5 \mathrm{~mL}$ of Radachlorin was i.v. injected into the mass according to the mass size. We used a diode laser, MILON-662 (Milon Laser Company, Russia) and Medlight cylindrical 10/20 radial diffuser and frontal diffuser as light delivery devices. About 3 hrs after intravenous injection, or $30 \mathrm{~min}$ after intralesional injection, a light dose of $200-300 \mathrm{~J} / \mathrm{cm}^{2}$ or $\mathrm{cm}$ of laser was irradiated onto the tumor or intralesionally with the light dose of $200-300 \mathrm{~J} / \mathrm{cm}^{2}$, or $\mathrm{cm}$.

Results There was partial tumor regression in three of the five primary tumors. In one case of metastatic node treated by intralesional injection and irradiation, tumor showed complete necrosis. But there was no effect in 2 cases of subcutaneous metastases. There were no side effects such as fever, chill and photosensitivity in any of the cases.

Conclusion The clinical effect of photodynamic therapy (PDT) using Radachlorin with 662 $\mathrm{nm}$ of laser light is not clear yet, but it seems to be a safe treatment for head and neck malignancy. We need to investigate the effect of this PDT system in untreated head and neck malignancies.

Korean J Otorhinolaryngol-Head Neck Surg 2011;54:271-7

Key Words Photodynamic therapy - Radachlorin · Recurrent head and neck malignancy.

\section{서 론}

전통적인 두경부암의 치료는 수술이나 방사선, 또는 항암 제를 단독 또는 병용하여 치료하는 것이다. 그러나 기존의 방 법은 각각 부작용이 상당해서 환자들은 고통이 적고 편안한 치료법을 기다려 왔다. 광역동치료는 비교적 근래에 임상에 사용된 치료법으로서 특정 파장의 빛에 의해 활성화되어 유 리 산소를 방출하는 물질인 광감작제를 환자의 몸에 주입한
후 종양에 감작물질이 많이 남아 있는 시간대에 빛을 쪼여 줌 으로써 종양부위만을 선택적으로 치료하는 방법이다. 이론 적으로는 종양부위만이 선택적으로 파괴됨으로써 통증이 적고 정상조직 손상이 적어 환자에게 편한 치료법이다. 이런 까닭으로 초기 표재성 구강암이나 후두암에서는 기능 보존 적 치료로서 자리 잡아 가고 있다. ${ }^{2,3)}$ 그러나 기존에 사용해 오 던 Photofrin은 $630 \mathrm{~nm}$ 의 빛을 이용하는 까닭에 조직투과 력이 4 5 mm에 불과해 암이 조금이라도 진행된 경우에는 
종양을 다 사멸시키지 못했고, 감작제가 몸에 머무는 시간이 길어서 환자가 6 주간을 어두운 곳에서 지내야 하는 불편함 이 있어 널리 쓰이지 못하였다.

최근에 개발된 Radachlorin ${ }^{\circledR 4)}$ 은 녹조류에서 추출된 엽 록소를 이용하여 만든 물질로서 $662 \mathrm{~nm}$ 파장의 빛에 의해 활성화되어 세포독성을 나타내는 물질로서 투과력이 $10 \mathrm{~mm}$ 정도이며 특히 체내에 체류하는 시간이 적어 주사 후 3 4시 간에 시술이 가능하며 주사 48 시간이 지나면 대부분의 약물 이 체외로 배출되기 때문에 2 일 뒤에는 환자가 빛을 볼 수 있 다는 장점을 가지고 있다. 더구나 hematoporphyrin 유도체 인 Photofrin과 달리 엽록소에서 만든 물질이라 인체에 부 작용도 없다는 장점을 가지고 있다(Table 1).

이에 저자들은 Radachlorin ${ }^{\circledR}$ 을 이용하여 재발한 두경부 암 환자를 대상으로 이 치료법의 효능과 부작용을 검토하고 자 본 연구를 고안하였다.

\section{대상 및 방법}

환자는 2009년 3월부터 건국대학교병원 이비인후과를 방문한 두경부암 환자를 대상으로 하였다. 대상환자의 조건 은 두경부 편평상피암 환자 중 항암제, 방사선, 수술 등의 치료를 모두 받고 재발하여 더 이상 기존의 치료를 받을 수 없는 환자를 대상으로 하였다. 총 10예의 환자를 대상으로 치료효과와 부작용을 확인하려 계획하였으나 최종적으로 6 명의 환자를 치료할 수 있었다.

수술 전날 환자를 입원시킨 후 수술 당일 아침 라다클로 린을 $1 \mathrm{mg} / \mathrm{kg}$ 용량으로 천천히 정맥주사한 후 3 시간 전후 하여 레이저광을 조사하였다. 조사장치 광원으로는 diode la- ser MILON-662(Milon Laser Company, Russia)를 사 용하였고 광전달 장치로는 사방으로 퍼지는 광섬유(radial diffuser fiber)와 전방조사 광섬유(frontal diffuser)를 사용 하였다.

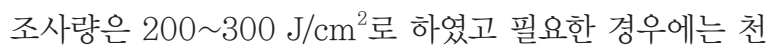
자기구를 이용하여 종양 조직 내로 직접 광섬유를 찔러 넣어 조사하였다(병변내 조사). 빛을 조사할 때 마취없이 시행할 수 있지만, 병변의 통증이 심하거나, 직접 찔러 조사하는 경 우에는 시술부위에 미리 국소마취를 하였고, 대부분의 경우 에는 전신 마취하에 시술하였다.

치료효과의 판정은 육안으로 관찰이 가능한 경우에는 치 료 2 일 후 육안으로 관찰하였고 4 주 후에는 $\mathrm{CT}$ 를 이용하여 효과를 판정하였다.

\section{결 과}

총 6 명의 환자에서 9 번의 치료를 시행하였고, 부위별로는 12 부위를 치료하였다. 한 예의 선양낭포암 환자와 한 예의 미 분화 비인두암을 제외하고 4명 모두 편평상피암 환자였으며, 증례 1 의 경우는 4 년 5 개월 전 협부암으로 국소절제술 및 경 부청소술후 재발한 환자로서 방사선 치료는 받지 않았으나 방사선 치료를 거부하여 광역동 치료를 받게 된 환자이며, 증례 2 의 경우는 선양낭포암으로 방사선치료에 잘 듣지 않 는 암이라 방사선치료 전에 광역동치료를 받게 된 환자였다 (Table 2).

환자 치료의 결과는 Table 3에 정리되어 있으며, 부위별로 는 피하전이 2예, 경부림프절 2예, 원발부 5 예를 치료하였다. 각 부위별 치료 결과는 피하전이에서는 전혀 효과가 없었으

Table 1. Comparison of radachlorin vs 1 st generation photosensitiser photofrin

\begin{tabular}{|c|c|c|}
\hline & Radachlorin injection & 1st generation photofrin \\
\hline Absorption wavelength (Max.) & $662 \mathrm{~nm}$ & $630 \mathrm{~nm}$ \\
\hline Depth of penetration into tumor & $>10 \mathrm{~mm}$ & $3-5 \mathrm{~mm}$ \\
\hline Maximum tumor uptake time (time of laser application) & $3-5$ hours & $>48$ hours \\
\hline Clearance period & $24-48$ hours (>98\% clearance) & $30-60$ days \\
\hline
\end{tabular}

Table 2. Patient's profile

\begin{tabular}{ccccc}
\hline Case & Original site/pathology & Stage & Previous treatment & PDT sites \\
\hline 1 & Buccal mucosa/SCC & rT4N2bMO & Surgery & Buccal tumor \& skin \\
2 & Lacrimal gland/ACC & rT4NOMO & Surgery & Maxilla \& skin \\
3 & Larynx/SCC & rT2NOMO & Surgery/RT & Larynx \\
4 & Nasopharynx/UDC & rTINOMO & RT/surgery & Nasal cavity, lateral wall \\
5 & Esophagus/SCC & rTxN2MO & Chemo/surgery/RT & Paraesophageal L/N \\
6 & Base of tongue/SCC & rT4N2bMO & Surgery/RT & Tongue \& metastatic L/N \\
\hline
\end{tabular}

PDT: photodynamic therapy, SCC: squamous cell carcinoma, ACC: adenoid cystic carcinoma, UDC: undifferentiated carcinoma, skin: subcutaneous metastatic nodule, RT: radiation therapy, L/N: lymph node 
PDT for Recurrent H\&N Malignancy I Lee YS, et al.

Table 3. Treatment result

\begin{tabular}{|c|c|c|c|c|c|c|}
\hline Case & PDT site & $\begin{array}{l}\text { Mode of injection } \\
\text { and illumination }\end{array}$ & $\begin{array}{l}\text { Light dosage } \\
\text { (mW/mins) }\end{array}$ & Response & $\begin{array}{l}\text { Further treat- } \\
\text { ment }\end{array}$ & Patient's status \\
\hline \multirow[t]{2}{*}{1} & $\begin{array}{l}\text { Buccal area } \\
\text { Skin }\end{array}$ & $\begin{array}{l}\mathrm{IVI} \\
\mathrm{El} \mathrm{C} \mathrm{FD}\end{array}$ & $800 / 8.5$ & $\begin{array}{l}\text { PR } \\
\text { NR }\end{array}$ & $2^{\text {nd }} P D T$ & \multirow[t]{2}{*}{ Died of other disease } \\
\hline & Buccal ( $\left.2^{\text {nd }} P D T\right)$ & El C FD & $800 / 8.5$ & $P R$ & RT & \\
\hline 2 & $\begin{array}{l}\text { Maxilla } \\
\text { Skin }\end{array}$ & $\begin{array}{l}\text { IVI } \\
\text { El C RD }\end{array}$ & $800 / 8.5$ & $\begin{array}{l}\mathrm{PR} \\
\mathrm{NR}\end{array}$ & $\begin{array}{l}\text { Surgery } \\
\text { /RT }\end{array}$ & Alive with disease \\
\hline 3 & Larynx & $\begin{array}{l}\text { IVI } \\
\text { II C RD }\end{array}$ & $800 / 8.5$ & PR & Surgery & Alive with disease \\
\hline \multirow[t]{2}{*}{4} & Nasal cavity & ILI, El C RD & $800 / 8.5$ & NR & $2^{\text {nd }} P D T$ & \multirow[t]{2}{*}{ NED 18 months } \\
\hline & & ILI, II C RD & $400 / 18$ & NR & Laser & \\
\hline \multirow[t]{2}{*}{5} & Lymph node & ILI, II C RD & $800 / 8.5$ & PR & $2^{\text {nd }} P D T$ & \multirow[t]{2}{*}{ Died of other disease } \\
\hline & & ILI, II C RD & $800 / 8.5$ & PR & Surgery & \\
\hline 6 & $\begin{array}{l}\text { BOT } \\
\text { Lymph node }\end{array}$ & ILI, II C RD & $800 / 8.5$ & $\begin{array}{l}N R \\
N R\end{array}$ & Surgery & Dead of disease \\
\hline
\end{tabular}

PDT: photodynamic therapy, IVI: intravenous injection, El: external irradiation, FD: frontal diffuser, RD: radial diffuser, ILI: intralesional injection, II: intralesional irradiation, PR: partial response, NR: no response, RT: radiation therapy, NED: no evidence of disease, BOT: base of tongue

Table 4. Complications of PDT with rhadachlonin

\begin{tabular}{|c|c|c|c|c|c|c|}
\hline Case & Pain/duration days & Edema & Fever & Chill & Skin discoloration & Others \\
\hline 1 & Moderate/3D & Moderate & No & No & No & \\
\hline 2 & Moderate & Slight & No & No & No & \\
\hline 3 & Moderate/7D & Moderate & No & No & No & Bleeding in the larynx \\
\hline 4 & No & No & No & No & No & \\
\hline 5 & Slight & Moderate & No & No & No & \\
\hline 6 & Moderate & Moderate & No & No & No & \\
\hline
\end{tabular}

PDT: photodynamic therapy

며, 경부림프절은 모두 병변내 자입치료를 시행하였고 3번의 치료 가운데 2 예에서 괴사를 확인할 수 있었다. 원발부위의 경우에는 5 예 중 3 예에서 종괴의 크기가 부분적으로나마 줄 어드는 것을 관찰할 수 있었다.

치료에 따른 부작용은 특별한 것이 없었다. 치료부위의 통 증은 비마약성 진통제로 가라앉힐 수 있었고 증례 1 의 경우 외에는 수일 내에 진통제 없이 지낼 수 있었다. 광감작제 투 여로 인한 부작용은 없었다. 광감작제 투여 후 48시간이 지 나서 광차단을 해제하였고 그 이후에도 가려움이나 착색반 응 등 피부 증상은 관찰할 수 없었다(Table 4).

\section{고 찰}

1세대 광감작제인 Photofrin을 이용한 두경부암의 치료는 구강, 구인두, 후두에서 발생한 초기암을 대상으로 행해져 왔 다. 이런 경우 비교적 치료 성적이 좋아 기존의 치료로 치료 하기 어려운 경우나 기존 치료법의 부작용을 피하고자 광역 동 치료가 사용되어 왔다. ${ }^{5)}$ 저자의 경우도 이전에 두경부암 환자를 대상으로 Photofrin과 Photogeme을 이용한 광역 동치료를 경험한 바가 있었다. ${ }^{1)}$ 그러나 Photofrin의 경우 630 $\mathrm{nm}$ 의 레이저광을 사용하기 때문에 투과력이 약하여 조금이 라도 진행된 경우 재발하는 경우가 많았고 약물의 체외배출 이 더디어 환자를 6 주간이나 암실에 머물게 해야만 하는 어 려움이 있었다. 더구나 Photogeme의 경우는 돼지 혈액을 재료로 하여 만들었기 때문에 발열, 오한 등의 과민 반응을 나타내는 경우도 있었다. 따라서 수술이나 방사선 치료 등 기존의 치료 방법과의 경쟁력을 갖기 위해서는 좀 더 긴 파 장의 빛에서 작용하는 새로운 광감작제에 대한 요구가 있었 고 이러한 열망에 따라 여러 광감작제가 개발되었다. 새로운 감작제가 갖추어야 할 요구조건은 조직 투과력을 높이기 위 해 기존의 Photofrin보다 장파장에서 활성되어야 했으며, 종양조직과 정상조직간에 농도차이가 커야 하며, 보다 빨리 배설되는 특성을 갖는 것이었다. 라다클로린은 이러한 특성 을 모두 가진 물질로서 환자에게 적은 부작용과 종양 선택 적 괴사에 더 효율적인 치료 효과를 나타내며 입원기간을 단 축시킬 수 있는 가능성을 가진 약물이었다. 특히 라다클로린 은 기존의 다른 2 차 광감작제보다 발생기 산소를 많이 발생 하며 보다 빠르게 배출되는 성질을 가져 임상적으로 매우 우 수한 약제로 판명되었다. ${ }^{6)}$

라다클로린은 spirulina라는 녹조류를 처리하여 얻은 복 
합 chlorine으로서 80\%는 chlorine e6(Fig. 1)의 형태로 $15 \%$ 는 purpurin, $5 \%$ 는 chlorine p6로 구성된 갈록색의 액 상 물질이다. 다른 연구 기관이 밝힌 바에 따르면 이 약물을 주입하고 3시간 전후하여 $662 \mathrm{~nm}$ 의 레이저광을 조사할 경 우 최대 조직침투력이 $10 \mathrm{~mm}$ 에 달하며, 종양/정상 농도비가 5 에 가깝고 48 시간에 $98 \%$ 약물이 체외로 배출된다고 보고 되어 있다. ${ }^{7)}$

라다클로린을 이용하여 기저세포암, 방광암, 기관지암, 식 도암8) 등 다양한 종양 89 예에서 광역동치료를 시행한 5 년간 의 연구 ${ }^{9}$ 에서 보듯이 상당한 치료 효과가 입증되었으나 국내 에서는 $\mathrm{Bae}$ 등 $^{10)}$ 이 자궁경부암 세포에서 라다클로린의 살상 효과를 실험적으로 입증한 것 외에는 아직 임상적용을 한 예 가 보고되어 있지 않다. 저자들은 기존의 Photofrin보다 강력한 라다클린을 이용하여 두경부암에서의 치료효과를 확인해 보고자 본 연구를 계획하였다.

그러나 본 연구에서는 결과가 말해 주듯이 눈에 뜨일 만 한 치료 성적을 얻지 못하였다. 이는 처음으로 사용하는 약 물이었기 때문에 이 약제의 안전성에 의문을 품은 임상심사 위원들로 인하여 대상 환자를 초기암이나 다른 치료를 받지 않은 신선한 암환자를 대상으로 하지 못하였고 수술이나 방 사선 치료 등 모든 치료 후에 재발한 환자만을 대상으로 하 여야 한다는 조건 때문에 진행된 암환자를 대상으로 제한한 것에서 그 이유를 찾을 수 있을 것 같다.

본 연구에서처럼 피하결절이나 진행된 원발부 실질내 종 양이나, 전이 림프절의 경우 종양 내부의 실질 압력(interstitial pressure)이 약제를 운반하는 종양 주변의 모세혈관내 압력보다 높게 되어 혈관내 주사로서는 약제를 종양 내부로 운반하지 못하는 현상이 발생할 수 있다. ${ }^{11,12)}$

광역동치료는 혈관내 감작제를 투여한 후 이 감작제가 종 양내부에 잘 침투한다는 전제하에 치료를 시행하는 방식이

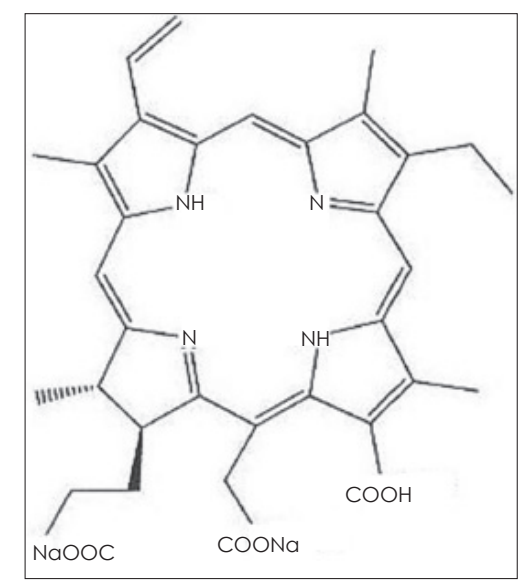

Fig. 1. A structural formula of one of the major components Redachlorin-sodium salt of chlorine $e_{6}$.
기 때문에 혈류가 풍부하고, 조직실질 내 압력이 낮은 부드러 운 종양에서는 치료 효율이 높지만 본 연구에서처럼 혈행이 나쁘고 조직 압력이 높은 재발 림프절이나 재발암의 경우는 그 효과가 별로 크지 않다는 것을 미루어 짐작할 수가 있다.

또한 광역동치료가 효과적이기 위해서는 조직내 산소가 풍부해야 하는데 재발한 종양조직내에는 상대적으로 산소가 적게 분포하게 되는 것도 치료효과가 적은 이유이기도 하다.

위에 언급한 두 가지 이유는 시험을 준비하는 과정에서 충 분히 예상된 것이었으나 임상 환자를 이용하는 시험인데다 가 본 약제가 국내에서 사용된 적이 없으며 국제적으로도 임 상에서 사용된 예가 극히 제한적이었기 때문에 부작용을 우 려한 임상심사위원회로부터 새로운 환자에서의 사용을 허락 받지 못한 상태였으므로 부득이 재발한 환자만을 대상으로 하게 되었다. 따라서 이번 연구는 예비적 시험으로 항암효과 가 있는지 여부를 확인하는 데 목표를 맞추어야 했고 기간 을 1년으로 제한한 연구였기 때문에 대상 수도 적을 수 밖에 없었다. 따라서 치료성적을 도출할 수 있는 시험은 아니고 향 후 새로운 암을 대상으로 보다 큰 규모의 임상시험을 할 수 있는지를 확인하는 성격의 시험이었고 이와 더불어 약제를 투여하였을 때 부작용은 없는지를 확인해 보려는 예비적 시 험이었다.

효과가 적을 것으로 예상됨에도 불구하고 증례 1 의 경우 표면조사를 한 협부 종양에서 표면적으로는 괴사소견을 보 였다. 증례 2에서도 상악동 내부를 채우고 있던 종양이 치료 를 통해 줄어든 경우에서 볼 수 있는 것처럼 재발한 경우라 도 혈류가 좋고 부드러운 조직에서는 표면 조사를 함으로써 좋은 치료효과를 기대할 수 있을 것으로 생각되었다. 그러나 같은 환자의 피하전이에 대하여는 거의 치료 효과가 없었다. 저자는 증례 1,2 의 피하전이의 경우 상기와 같은 이유로 치 료효과가 적었던 것으로 판단하여 증례 3 부터는 종양조직 내로 직접 광감작제를 투여한 후 레이저 유도관을 직접 종양 내로 삽입하여 치료하는 방식으로 치료를 진행하였다. 이러 한 삽입치료도 재발암에서 효과적이라는 논문이 보고 되어 있다. ${ }^{13)}$ 증례 4 , 비강에 재발한 비인두암 환자의 첫 번째 치 료는 찔러 넣기 힘든 부위에 종양이 위치하여 기술적인 이유 로 부득이 강내 조사를 실시하게 되었다.

광감작제 투여량은 종괴의 크기와 단단한 정도에 따라 일 정치 않았지만 가능한 최대량을 주사하였고 라다클로린 용 액 2 5 mL를 주입하였다. 주입 30분 후에 초음파로 유도하 거나 눈으로 보면서 $1 \mathrm{~cm}$ 간격으로 유도관을 찔러 넣은 후 유도관을 통하여 광섬유를 종양 내로 집어넣어 레이저를 조 사하였다. 이렇게 치료한 전이 림프절 4 예 중 증례 5 번 환자 에서 실시된 2 차례의 자입치료에서 치료된 부위의 종양이 
Fig. 2. Computed tomography of case 5. Preoperative view of $4.2 \mathrm{~cm}$ right supraclavicular mass (arrow) invades right subclavian vessels and prevertebral fascia $(\mathrm{A})$. Follow up view after PDT. Tumor mass decreased and became necrotic in the central area. But deeper mass remains same as before $(B)$.
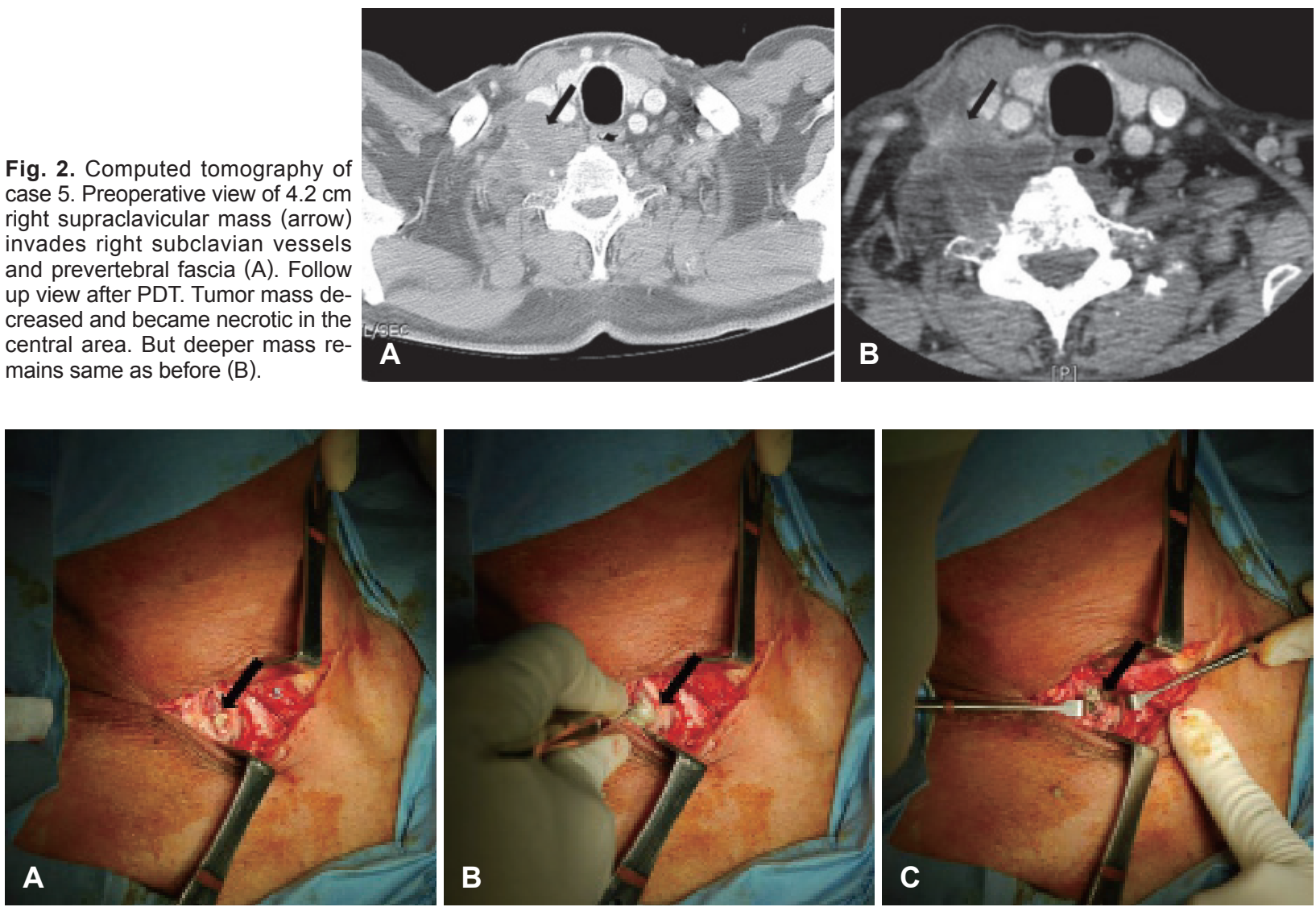

Fig. 3. Intraoperative finding of case 5. Necrotic lesion between trapezius and sternocleidomastoid muscle (S) was identified (A). Metastatic node became soft and necrotic (B). After removing necrotic tissue we could observe cavitary lesion inside the tumor (C).

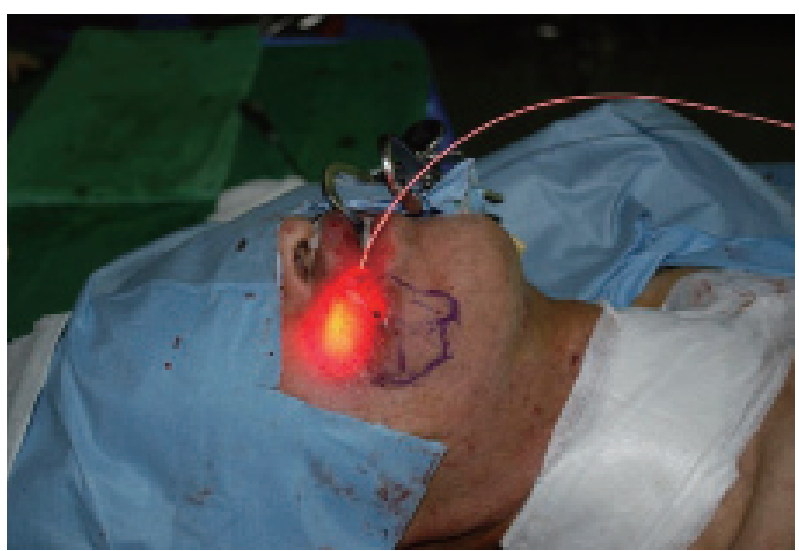

Fig. 4. Operation view of photodynamic therapy. $2 \mathrm{~cm}$-radial diffuser irradiates tumor mass where Radachlorin accumulates selectively.

모두 괴사된 것을 수술로 확인할 수 있었다(Figs. 2 and 3) 전이 림프절이 워낙 크고 깊어 깊은 부위에는 감작제를 주사 할 수 없었기 때문에 깊은 부위에는 치료 효과가 없었으나 표 면부위 종양은 괴사되어 치즈모양의 걸죽한 물질로 변해있 었다. 이것은 감작제가 잘 침투될 수 있다면 살상효과를 얻 을 수 있다는 증거를 보여준 것이라 생각된다. 따라서 향후
종양내부에 광감작제가 고루 분포할 수 있는 주입법을 개발 하고 종양내부의 감작제 농도를 측정하는 방법을 적용하여 충분한 농도를 확인하고 시술한다면 보다 믿을 만한 결과를 얻을 수 있을 것으로 기대한다.

광역동치료를 시행한 원발부 종양은 5 예 중 3 예에서 부분 적인 반응을 보였다. 증례 1 , 협부암의 경우(Fig. 4) 협부 종 양이 다소 부드럽고 혈행이 풍부했었는데 이 경우 두 번의 치료 모두에서 종양 표면 괴사를 유도할 수 있었다. 다만 이 환자의 경우 종양의 성장 속도가 워낙 빨라 치료효과도 잠시 에 불과하였고 종양이 계속 진행하는 바람에 방사선 치료를 시행할 수밖에 없었다. 증례 2 , 상악동을 침범한 선양 낭포 암 환자의 경우도 치료 후 종양의 크기가 다소 감소하는 데 그쳤는데 이 환자의 경우 여러 차례의 수술로 종양 주변의 혈 행이 많이 차단되었던 점으로 인해 치료 효과가 반감되지 않 았나 추정된다. 그러나 광역동치료법으로는 선양낭포암이라 하더라도 약제만 침투된다면 편평상피암과 다를 바 없이 치 료가 가능하다는 점을 알 수 있게 해준 경우이기도 하다. 증 례 3 , 재발한 후두암의 경우에는 감작제를 정맥혈관으로 투 여하고 레이저 조사는 초음파 유도하에 갑상연골과 윤상연 

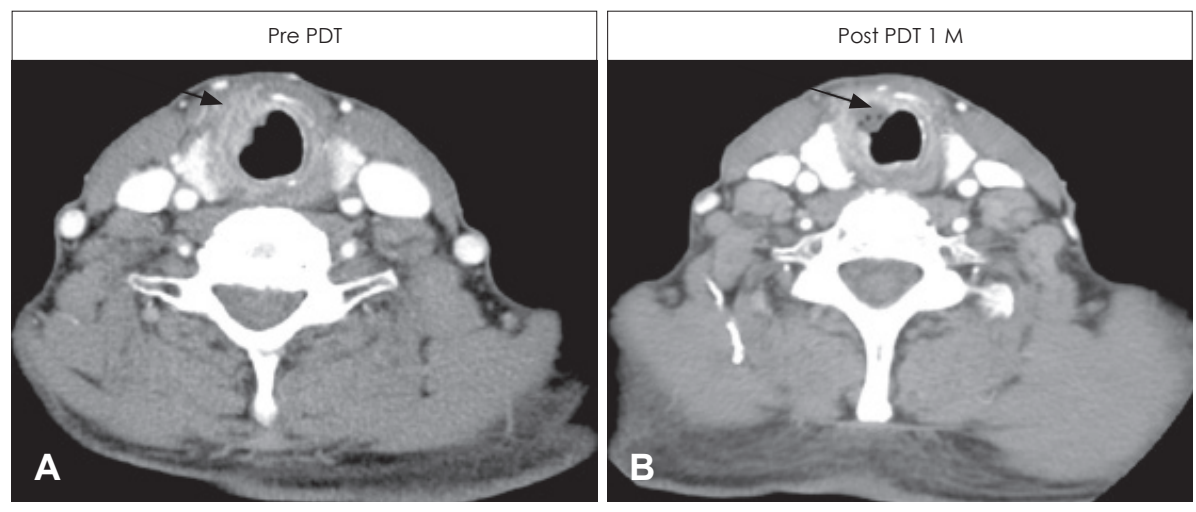

Fig. 5. Pre and post PDT 1 month CT of case 3. Arrow indicates tumor $(A)$ and necrotic area (B) in the larynx by intralesional PDT.
골 사이를 통하여 총 4 회의 자입치료를 시행하였고 종양부 종을 염려하여 미리 기관절개를 하였다. 치료 후 치료부위에 약간의 통증은 있었으나 점차 가라앉았고 4 일 후에는 별 통 증을 느끼지 못하였다. 수술 23 일째 후두에서 출혈이 발생하 여 기관공으로 출혈이 있었으나 수분 후 저절로 멎었다. 치료 한 달째 CT상 종양 내부에 광섬유가 들어간 자리를 따라서 괴사된 소견이 보였다(Fig. 5). 그러나 다른 부위에는 종양 이 여전히 남아 있어 결국 후두전절제술을 시행하였다. 이 경 우도 이전의 수차례의 레이저 수술과 방사선 치료로 혈행이 많지 않은 상태에서 광감작제가 종양 내부까지 도달하지 못했 기 때문에 치료가 제대로 되지 않았을 것으로 추정된다. 증 례 4, 재발한 비인강암의 경우는 처음 치료는 혈관 주사 후 강내 치료를 하여 종양이 없어졌으나 한 달 뒤 다시 커져 두 번째 치료시에는 병변내 주입 후 자입치료를 시도하였다. 그 럼에도 불구하고 다시 재발하여 결국 레이저 소작술로 치료 한 환자이다. 이 환자도 여러 차례의 수술과 방사선 치료로 혈행이 차단된 상태로서 감작제 침투가 제한되었고, 해부학 적 위치가 자입 치료하기에도 어려워 재발을 하지 않았나 생 각된다. 증례 6 , 재발한 설근암의 경우 종양자체가 너무 단단 하여 감작제를 주입하는 데 어려움이 있어 충분한 양의 감작 제를 투입할 수 없었다. 향후에는 치과용 주사기를 이용하거 나 특수한 주입장치를 사용하면 좀 더 많은 양의 감작제를 투여할 수 있을 것으로 생각한다.

이상의 치료 결과를 종합해 보면 본 연구에서 이론적으로 는 기존의 약제에 비해 우수한 특성을 가진 감작제를 사용하 여 치료하였음에도 불구하고 예상보다 효과가 좋지 않았다. 그 이유로는 첫째, 너무 진행된 암종을 치료하였다는 점이다. 특히 대상환자가 방사선 치료나 수술을 받은 환자들이라 혈 행이 좋지 않았고 종양이 단단하여 감작제 침투가 어려웠던 환자들이었다는 점이다. 그럼에도 불구하고 일부에서 괴사를 유도할 수 있었던 점으로 미루어 만일 혈행이 풍부하여 조직 내 산소가 비교적 풍부한 점막에서 기원한 초치료 종양환자 에서는 좋은 치료 결과를 기대할 수 있을 것이란 희망을 갖
게 하였다. 따라서 이번 예비 치료 결과를 바탕으로 구강과 후두의 초기암에서 첫 치료를 시도해 보는 것이 좋을 것으로 기대되었다.

한편 이 감작제는 기존의 Photoheme과 달리 약제로 인 한 부작용이 없었다. 주사 후 나타나는 발열 반응이나 오한 이 없었고, 피부 가려움이나 변색 반응도 보이지 않았다. 무 엇보다 투여 후 48시간 후면 환자가 빛을 볼 수 있다는 점도 대단한 이점이라 하겠다. 그러나 조직괴사로 인한 부종이나 통증은 기존 약제와 비슷한 양상을 보였다.

\section{Acknowledgments}

This work was supported by the faculty research fund of Konkuk University in 2009.

\section{REFERENCES}

1) Lee YS. Photodynamic therapy in head and neck malignancy. J Clin Otolaryngol Head Neck Surg 2004;15:214-21.

2) Rigual NR, Thankappan K, Cooper M, Sullivan MA, Dougherty T, Popat SR, et al. Photodynamic therapy for head and neck dysplasia and cancer. Arch Otolaryngol Head Neck Surg 2009;135(8):784-8.

3) Biel MA. Photodynamic therapy treatment of early oral and laryngeal cancers. Photochem Photobiol 2007;83(5):1063-8.

4) Uzdensky AB, Dergacheva OY, Zhavoronkova AA, Reshetnikov AV, Ponomarev GV. Photodynamic effect of novel chlorin e6 derivatives on a single nerve cell. Life Sci 2004;74(17):2185-97.

5) Schweitzer VG. Photofrin mediated photodynamic therapy for treatment of early stage oral cavity and laryngeal malignancies. Lasers Surg Med 2001;29(4);305-13.

6) Douillard S, Lhommeau I, Olivier D, Patrice T. In vitro evaluation of Radachlorin sensitizer for photodynamic therapy. J Photochem Photobiol B 2010;98(2):128-37.

7) Prialov VA, Lappa AV, Seliverstov OV, Faizrakhmanov AB, Yarovoy NN, Kochneva EV, et al. Clinical Trials of a New Chlorin Photosensitizer for Photodynamic Therapy of Malignant Tumors. In: TJ Dougherty, editor. Optical methods for tumor treatment and detection: Mechanisms and technologies in Photodynamic therapy XI; 2002 Jan 19; San Hose Califonia. Proc. SPIE 4612;2002. p.178-89.

8) Filonenko EV, Sokolov VV, Chissov VI, Lukyanets EA, Vorozhtsov GN. Photodynamic therapy of early esophageal cancer. Photodiagnosis Photodyn Ther 2008;5(3):187-90.

9) Prialov VA, Lappa AV, Kochneva EV. Five Years' Experience of Photodynamic Therapy with New Chlorin Photosensitizer. In: Bergh HV, Vogel A, editors. Therapeutic Laser Applications and Laser-Tissue Interactions II; 2005 Aug 19; Munich, Germany. SPIE5863;2005. p.18698. 
10) Bae SM, Kim YW, Lee JM, Namkoong SE, Han SJ, Kim JK, et al. Photodynamic effects of Radachlorin on cervical cancer cells. Cancer Res Treat 2004;36(6):389-94.

11) Boucher Y, Baxter LT, Jain RK. Interstitial pressure gradients in tissue-isolated and subcutaneous tumors: implications for therapy. Cancer Res 1990;50(15):4478-84.
12) Gutmann R, Leunig M, Feyh J, Goetz AE, Messmer K, Kastenbauer $\mathrm{E}$, et al. Interstitial hypertension in head and neck tumors in patients: correlation with tumor size. Cancer Res 1992;52(7):1993-5.

13) Lou PJ, Jäger HR, Jones L, Theodossy T, Bown SG, Hopper C. Interstitial photodynamic therapy as salvage treatment for recurrent head and neck cancer. Br J Cancer 2004;91(3):441-6. 